\title{
Brecht and Exile: Poetry after Weimar, Poetics during Blitzkrieg
}

\author{
THEODORE F. RIPPEY \\ Bowling Green State University
}

Man sagt mir: iss und trink du! Sei froh, dass du hast!

Aber wie kann ich essen und trinken, wenn Ich es dem Hungernden entreiße, was ich esse, und

Mein Glas Wasser einem Verdurstenden fehlt?

Und doch esse und trinke ich.

-Bertolt Brecht, "An die Nachgeborenen"

$(1938)^{1}$

Kulturkritik findet sich der letzten Stufe der Dialektik von Kultur und Barbarei gegenüber: nach Auschwitz ein Gedicht zu schreiben, ist barbarisch, und das frisst auch die Erkenntnis an, die ausspricht, warum es unmöglich ward, heute Gedichte zu schreiben.

-Theodor W. Adorno, "Kulturkritik und Gesellschaft" (1951)²

Here we have a Brecht poem grappling with the barbarism of self-preservation in barbaric times - times that, if we follow Adorno, form the penultimate phase of a process that sees the writing of poetry itself become barbaric. Adorno's point, made in the context of a broader argument about cultural criticism and the estrangement of intellectual labor from social life, is not the prohibitive injunction it is often taken for. Rather, he insists that it is impossible to carry 
out and understand poetic creation as one did before the Holocaust. Critics in a pre-Auschwitz age could take no notice of the relationship between culture and barbarism (a convenient elision) or insist on an opposition of the two that poetry apparently confirmed (a convenient illusion). Auschwitz forced the issue by making barbarism's connection with every cultural process and product undeniable (regardless of whether the postwar intelligentsia recognized that link). And here Brecht and Adorno, unlikely a pair as they may be, shared a concern about how creative acts we wish only to laud are bound up with destructive acts we wish only to condemn; indeed, Brecht's struggles over exile writing in the late 1930s and early 1940s anticipated Adorno's post-1945 claim.

How can phenomena that are culturally coded as beneficence and malfeasance intertwine, even be one and the same? This problem of doing harm while doing good, on the map of German letters at least since Nietzsche's Jenseits von Gut und Böse, influenced Brecht's contemplation of surviving and writing in exile in equal measure. In what follows, I will examine a selection of poems and journal entries from the years 1937 to 1940, in order to characterize the criminality of exile writing and assess that problem's impact on his poetics during a time in which German fascism increasingly gave the impression of being an unstoppable force. My use of the term criminal is not provocation for its own sake. Rather, I explore how a heightened sense of the ethical breaches of writing, coupled with the liquidation of established networks and concepts of literary communication in the course of the Blitzkrieg, turned exile into a literary laboratory, in which new relationships between poetics and politics could be thought and forms of writing capable of future resonance could be tested. Stated briefly: an acute sense of writing's transgressions spurred a reconceptualization of literary transmission and duration.

In this reconceptualization, Brecht had to come to terms with two related splits that registered as profound losses. The first involved the divorce of the emotional and the intellectual, pursued with enthusiasm in the neusachlich cultivation of Kälte during the Weimar years, that left its proponents ill-equipped to respond to the fascist dynamization of the masses in the 1930s. The second was the divorce of poetics from history: acknowledging this disabused writers once and for all of the notion that they could exert even slight degrees of direct social influence through their work. In Brecht's case, we find recognition of the impossibility of affecting society via his texts along with realization that a crucial link between social and literary realities persists: the latter cannot influence yet also cannot exist without the former.

\section{Eating and Drinking}

While the balladeer of the Dreigroschenoper points out that morality is a luxury of those who take eating for granted, the poet of the Svendborger Gedichte insists that he has no right to fill his belly: 
Es ist wahr: ich verdiene noch meinen Unterhalt

Aber glaubt mir: das ist nur ein Zufall. Nichts

Von dem, was ich tue, berechtigt mich dazu, mich satt zu essen.

Zufällig bin ich verschont. (Wenn mein Glück aussetzt

Bin ich verloren.) (BFA 12: 85)

The sense of absurd accident is almost palpable in these lines from "An die Nachgeborenen." There is consternation over salvation, however temporary, implicitly coupled with the painful knowledge that those left behind are still suffering in the direct struggle with Hitler's dictatorship. "Ich, der Überlebende," a poem from the brief Gedichte im Exil collection, makes the sense of shame explicit. It is friends who are dying:

Ich weiß natürlich: einzig durch Glück

Habe ich so viele Freunde überlebt. Aber heute Nacht im Traum

Hörte ich diese Freunde von mir sagen: "Die Stärkeren überleben"

Und ich hasste mich. (BFA 12: 125)

It is quite a bind for the poet: in striving to express the guilt of survival, one is only made more excruciatingly aware of the fact of one's own survival and the fact of others' death that accompanies it.

This guilt and the desire to overcome it through constructive action are the only things that still link the poet with his friends, for exile has put an end to their physical contact. The epigraph of the Svendborger Gedichte captures the sensation of being cut off: "Geflüchtet unter das dänische Strohdach, Freunde / Verfolg ich euren Kampf" (BFA 12: 7). The first line both evokes the northern European coastal setting and underscores the tentativeness of the exile's security, but it is the possessive in the second line that leaps out. Euren makes it plain that the struggle is no longer the poet's: the lyric voice cannot enunciate the language of the fight, it can only comment on the action. Even the effort to follow the action is compromised by severance. The poet's words, which he sends to his comrades, are tenuously sourced: "Vergilbte Bücher, brüchige Berichte / Sind meine Unterlage" (BFA 12: 7). The final line, while not devoid of optimism, captures the terrible conditionality of the moment: "Sehen wir uns wieder / Will ich gern wieder in die Lehre gehn" (BFA 12: 7). One senses the formally reflective touch in "gehn" as a counterpart to "gern," but also a more resonant emotional note: the colloquial orthography evokes orality and thus establishes a kind of intimacy that even the informal address cannot. As immersed as Brecht is in the geopolitics of the late 1930s, the Svendborg poet reminds us at such select moments of the acute need for interpersonal contact amid the struggles of exile.

It is in following the fight that the lyric voice acquires both the sense of the arbitrariness of survival and the intensifying self-hatred captured in "Ich, der Überlebende." That the lyric subject is alive may quite simply be absurd; that it lives as others die constitutes a moral dilemma (indeed, transgression) that is explored further in part two of "An die Nachgeborenen." This is the 
historical-narrative passage, in which the lyric voice offers a concise chronicle of time allotted on earth. It begins, "In die Städte kam ich zur Zeit der Unordnung / Als da Hunger herrschte" (BFA 12: 86). One stanza later, the lyric voice reveals that it was able to nourish itself despite the collective hunger: "Mein Essen aß ich zwischen den Schlachten / Schlafen legte ich mich unter die Mörder / Der Liebe pflegte ich achtlos / Und die Natur sah ich ohne Geduld" (BFA 12: 86). There is no exclamation of guilt here, but the spare, stark contours of the figure who eats among the hungry and sleeps among the murderers speak for themselves: in the interest of survival, the lyric subject implicates itself in the carnage.

This part of the poem raises an important question of temporality. It is constructed as retrospection, but there is a significant degree of chronological openness. The initial verse suggests that the section describes a time anterior to the now of the first part. Yet the refrain- "So verging meine Zeit / Die auf Erden mir gegeben war"- - suggests a look back from (perhaps even after) life's end that takes in all moments before, during, and after the dark times lamented in the poem's opening line. To speak from such a temporal position requires displacement of the lyric voice to a time not yet experienced by the writer, which signals three things: first, that we have reached the apex of the poem's artifice, as the temporal dislocation breaks the conceit of the present-moment address maintained perfectly by the poem's first and third parts; second, that the lyric voice perceives itself in a situation that is unlikely to see significant change before the poet's body expires; and third, that the general tenuousness of existence and decay of geopolitical order that defined exile are significant factors in that perceived and anticipated absence of change. The effect for the subject is to understand itself existing in a temporal stretch in which the distinctions between past, present, and future become increasingly insignificant: Brecht's lyric voice has moved into what he will later call the "Inzwischenzeit" (BFA 26: 414). As have its utterances, as the poem "Gedichte im Exil" attests: "Sie [the poems] werden nicht angerufen. Sie werden nicht angehalten. / Niemand schilt sie und niemand lobt sie. / Da sie keine Gegenwart haben / Suchen sie sich Dauer zu verleihen" (BFA 14: 311, my emphasis). In conjunction, the texts convey the need to achieve in his work a lasting significance in the absence of immediate impact: duration without presence.

This erosion of linear temporality has significant implications for the questions of transmission and duration that I will explore in detail below, but it also connects with the poem's problematization of corporality and nature. As historical time measured incrementally appears to lose force, making deliberative action superfluous, awareness of sheer physicality is heightened. Consider again the lines about eating, sleeping, love and nature cited above. The lack of care ("achtlos") that the lyric voice concedes in the fostering of love hollows out that fostering - a form rehearsed without investment of sentiment. The recalled lack of patience with nature suggests both the char- 
acteristically modern desire to impress human design on the whole of sphere of earthly life and the begrudging acknowledgment of the physical world's recalcitrance. This recalcitrance comes from without and within, as the body demands nourishment and rest regardless of the mind's prerogatives-and regardless of time, which is irrelevant to the body's needs. The more the subject's focus falls on these, the less relevant time becomes. The sense of time's suspension remains, however, always partial, and the confession of neglect cannot be read as a yearning for what Ronald Speirs calls the "selfforgetting immersion in sheer sensation" that the lyric voice of Hauspostille often desires. ${ }^{3}$

The confessions in this stanza are spurred by the recognition that the intellectual disavowal of the corporal, grounded in a fallacious distinction between the human and the natural, was ill-conceived to begin with. Emerging awareness of this wrong move adds a semantic dimension to such lines as "Ich vermochte nur wenig. Aber die Herrschenden / Saßen ohne mich sicherer, das hoffte ich" or "Die Kräfte waren gering. Das Ziel / Lag in großer Ferne / Es war deutlich sichtbar, wenn auch für mich / Kaum zu erreichen" (BFA 12: 86). "Das hoffte ich" and "für mich" suggest a retrospective awareness of shortcoming and a need to reassess. What was it that limited awareness and held efforts in check? Following as they do the lines about love and nature, these verses invite connected contemplation of the lack of political impact and the disavowal of the natural, corporal, and emotional. We commonly regard the body and its irrational impulses as potential vehicles of barbarism, the intellect as civilization's author. But the verse-sequencing here implies that intellectual projects (political or otherwise) too severely abstracted from the physical world run the risk of failure, perhaps even of promoting rather than curtailing barbarism. Indeed, the next verse makes plain that even the ordering work of civil engineering led (and by implication, leads) ultimately back to the primal, the pre-civilized: "Die Straßen führten in den Sumpf zu meiner Zeit" (BFA 12: 86). Doing the work of civilization is also undoing it. This recognition could stoke a productive reconceptualization of the intellectual and the corporal, but the poem conveys the failure of the poet's generation to achieve that goal. In the increasing awareness of this lies a second sense of transgression that interlinks with the first, for it is the body that drives the poet to nourish himself while others go without.

These problems of corporality and emotion were neither new to Brecht nor unknown to other observers of the times. The lyric voice's allocution to the transgression of detached, deficient loving resonates, for example, with Freud's discussion of love as a "Grundlage der Kultur" in parts IV and V of Das Unbehagen in der Kultur. ${ }^{4}$ In Freud's conceptualization of love as a libidinal phenomenon, the libidinal is not strictly confined to the sexual; it involves the corporal and emotional ties humans establish as a means of resisting the atomizing forces of increasingly complex systems of modernity. Libidinal 
networks form part of the durable undergirding of psychic life, and they always have the potential to disrupt social organization even as they promote intersubjective connection-hence the social need to regulate the libido.

The detached "cool conduct" of the interwar subject, which Helmut Lethen has so effectively characterized, entailed a disavowal of the visceral and banishment of emotion that reflected either sub-consciously rooted aversion to, or conscious theoretization of, love as liability. ${ }^{5}$ The "tiefwirkende Desorganisation" of the decades following World War I, argues Lethen, called for a functional I (Ich) capable of managing the shock of lost social hierarchies and shattered communities. This functional I emerged as a product of the neusachlich split personality, which oscillated between "Einverständnis mit dem Objektstatus des Menschen" and recalcitrant attachment to the idea of "Machbarkeit des Schicksals." ${ }^{\prime \prime}$ Lethen sees in the neusachlich "Bejahung des Gangs der Dinge," which appears to reject Enlightenment-inspired claims of agency, a paradoxical attempt to involve oneself in processes of external control, "um in der List des Einverständnisses an der Kraft des historischen Prozesses teilzuhaben und den Glanz der Täterschaft zu erneuern.”’

In the kalte persona, its most sovereign social mask, the functional I used systematic classification to achieve management of modernity's chaos: "Alle Phänomene," notes Lethen, "vom Körperbau bis zum Charakter, von der Handschrift bis zur Rasse werden klassifiziert." for the neusachlich subject is "distinguo ergo sum"; and the most important distinction was that of the functional I itself, an operation that turned on thoroughly detaching self from other and compartmentalizing the affective phenomena that always connect the two. The kalte persona permitted the human subject an "angstfreien Zugang zum Prozess der Modernisierung" and a "Freiheitsspielraum" within that process. This freedom was more mythical than real, but in imagining it, the neusachlich intelligentsia set the best course it could for surviving modernity.

That survival came at a cost, especially since Kälte was not exclusive property of liberal intellectuals. Its role, for example, in the modes of subjectivity that were necessary factors in the Auschwitz equation did not go unnoticed by later theorists. We find an example in Adorno's discussion of the type of person that could devise a rail transport system to send people to a death camp without considering what would happen to those people once they reached their destination:

Bei dem Typus, der zur Fetischisierung der Technik neigt, handelt es sich um Menschen, die nicht lieben können. Das ist nicht sentimental und nicht moralisierend gemeint, sondern bezeichnet die mangelnde libidinöse Beziehung $\mathrm{zu}$ anderen Personen. Sie sind durch und durch kalt, müssen auch zuinnerst die Möglichkeit von Liebe negieren, ihre Liebe von anderen Menschen von vornherein, ehe sie sich nur entfaltet, abziehen. Was an Liebesfähigkeit in ihnen überlebt, müssen sie an Mittel verwenden. ${ }^{9}$ 
A crucial point here is that those who fetishize technology have a need to love but are incapable of fostering and expressing the sentiment interpersonally. They thus require surrogate means, and investing affection in objects is one alternative. We see another in the obsessive, at times orgiastic Körperkultur of the golden twenties. Nazi physical culture, crowd choreography, and the Führer cult offered further possibilities. In any of these instances, the libidinally deficient could find in the ephemeral corporal high of the mass a means to fill the void that was coextensive with the absence of intersubjective libidinal bonds.

This is not to draw a direct line of culpability from technology-praising neusachlich writers or 1920s boxing promoters to the gates of the death camps. It is, however, to identify a problem of modernity that connects them all. The Svendborg collection suggests increasing consciousness of this connection, already in 1937. It is no accident that the 39th line of "An die Nachgeborenen" ends with Mörder and the following line begins with der Liebe. The two verses convey distinct thoughts, but the use of the archaic verb form creates a perfect grammatical logic - first noun, genitive article, second noun-that allows a semantic link to persist through the formal pause. What would such metaphorical murderers represent? Constructing the cold persona of interwar modernity involved doing away with sentiment deemed obsolete, and Brecht himself (if a text like the Dreigroschenoper can stand as an example) was certainly invested in killing off the traditional bourgeois species of love. But in the preoccupation with love (friendship in particular) in "An die Nachgeborenen," one sees an increasing retrospective anxiety that the campaign to wipe out traditional love may have perilously foreclosed other libidinal options. The detached technocrat, the cynical artist, the SS man: any of these could perpetrate a murder of love, and the subject represented by the lyric voice of "An die Nachgeborenen" had become too comfortable with such killing. The self-critical consciousness of this comfort both intensified feelings of guilt and lent formal and thematic focus to the work of undoing the collateral damage of Kälte.

\section{Talking about Trees}

Where lies the evidence of such undoing? The closest thing to an admission of criminal guilt provides part of the answer:

Was sind das für Zeiten, wo

Ein Gespräch über Bäume fast ein Verbrechen ist

Weil es ein Schweigen über so viele Untaten einschließt!

Der dort ruhig über die Straße geht

Ist wohl nicht mehr erreichbar für seine Freunde

Die in Not sind? (BFA 12: 85)

The passage's implicitly and explicitly identified transgressions must be disentangled. First, we have the famous line about conversations about trees, which 
in isolation reads as a non sequitur. (More on fast in a moment.) Next, we have the Untaten, which remain unspecified. And finally, we have the accusatory observation of the calm pedestrian no longer reachable for his friends. The first and third are related, if not causally then structurally and functionally. They each involve a failure of registry and/or of discursive engagement. Crucial information makes no traceable impact on the given recipient; in one instance because the recipient is occupied with insignificant discourse that either blocks the crucial information at point of entry or paves over it, in the other because the recipient is either oblivious to the communicative signal or has received and repressed it. In either case, there is a breakdown in the system of communication, a breakdown on which the misdeeds depend.

By implicating those who perceive themselves as innocent in the misdeeds' diffuse web of responsibility, the poet throws down the ethical gauntlet for the general citizen walking across the street and the aesthetically inclined citizen who talks about trees. This particular poetic rendering of implication has analogs across the Svendborg collection, most notably in "An die Gleichgeschalteten," which begins with a characteristic connection of ethical dilemma and material crisis:

\author{
Um sein Brot nicht zu verlieren \\ In den Zeiten zunehmender Unterdrückung \\ Beschließt mancher, die Wahrheit \\ Über die Verbrechen des Regimes bei der Aufrechterhaltung der Ausbeutung \\ Nicht mehr zu sagen, aber \\ Auch die Lügen des Regimes nicht zu verbreiten, also \\ Zwar nichts zu enthüllen, aber \\ Auch nichts zu beschönigen. Der so Vorgehende \\ Scheint nur von neuem zu bekräftigen, dass er entschlossen ist \\ Auch in den Zeiten zunehmender Unterdrückung \\ Sein Gesicht nicht zu verlieren, aber in Wirklichkeit \\ Ist er doch nur entschlossen \\ Sein Brot nicht zu verlieren. (BFA 12: 48)
}

In diction, rhythm, even syntax, the passage evokes the dual ethical edge of the pragmatic deliberation that informs communication under dictatorship. The $u m \ldots z u$ construction that begins the poem signals immediately that matters of means and ends will be central, and the passage's three verse-initial verbs"Beschließt" (line three), "Scheint" (nine), and "Ist" (twelve)—economically establish a complex model of the intentions and consequences (intended and unintended, apparent and actual) that shape communication. Even more so than in "An die Nachgeborenen," issues of criminality and culpability are in the foreground. The primary reason, of course, is that this poem is literally an address to ordinary Germans (it was broadcast from Moscow in 1935), while "An die Nachgeborenen" was addressed to later generations. But Brecht knew then as we know now that present and future readers would process each of 
these poems, and the lyric voice's fixation on the perils of silence in both suggests Brecht's conviction that the problem of communicative choices and communicative acts-of what to convey and how to convey it-was both acute and chronic. ${ }^{10}$

In their exposition of this dilemma, the poems pair the problem of communicative connection with that of libidinal connection, creating the opportunity for the reader to link critical contemplation of each. The bulk of the verses' explicit interrogation focuses on conscious aspects of communication, while the poems' material components - their letters and lines, words and sounds-evoke sentiment and sensuality obliquely, via either metaphorical images or direct (yet non-linguistic) sensory impressions. In interweaving emotional impulses and deliberative processes at the thematic and formal level, the texts push forward the conceptualization of literature as a diachronic means of sentimental and intellectual communication, enhancing the poetic medium's capacity to bring the visceral and intellectual realms, artificially split by the cooling trend that began in the mid-1920s, back into productive interplay.

It is in this light that the trees must be considered. Technically, there are three communicating entities in the tree verse of "An die Nachgeborenen": a group (of at least two) that talks about trees (it is, we recall, a Gespräch); the lyric voice, which speaks of that conversation; and the poet, who communicates obliquely with reader through the lyric voice. It requires no analytical contortion to detect resonance between (though by no means identity of) the three. A chestnut tree is the definitive motif of "Gedanken über die Dauer des Exils" (BFA 12: 82), palm and citrus trees dot the settings of the Hollywoodelegien (BFA 12: 113-116), and in the journals Brecht writes frequently of trees in his descriptions of Swedish and Finnish places of residence. ${ }^{11}$ To the extent, then, that the lyric voice levels a criticism, it is directed at least in part at the author, whose preoccupation with trees extended back to the Hauspostille.

Speirs addresses an example of this preoccupation in his analysis of the Hauspostille poem "Vom Klettern in Bäumen," in which the reader is "instructed on how to sink into the experience of swaying with the evening wind in the topmost branches of a tree so completely as to become a part of it, thereby participating in the world of nature which exists outside consciousness and, hence, outside time." 12 "An die Nachgeborenen," then, reads in part as a critical response to "Vom Klettern in Bäumen." In the later work, the tree verse concisely alludes to the seductive yet fallacious notion of escaping the dehumanizing grind of the social via flight into a natural space outside time, the impossibility of which is underscored by the street image in the verses that immediately follow. More pointedly, "An die Nachgeborenen" suggests responsibility in the failure to recognize what talking of trees blocks or hinders. The term "ein Verbrechen" indicts tree-talk, a synecdochal representation of discourse on natural beauty (or beauty generally) and inclination toward 
sensual pleasure. But "fast" stops the verse short of thoroughgoing condemnation: there must, it intimates, be redeeming potential in such talk. It is, the verse implies, to be re-functionalized, not discarded. And the "wohl" in the poem's tenth line couples with the question mark at the end of the eleventh to hint that the pedestrian could be made reachable. This transgression is not as final as eating when others go hungry. But can one really talk of trees in a way that makes the silence legible und thus makes glimpses and echoes of the misdeeds perceptible? How can the smooth-browed communicant become more reachable? The answer involves facing reality.

\section{Clouds of dust, spaces of battle}

Among the ruptures that profoundly influenced exile literary production, Bettina Englmann emphasizes the break in poetological discourse regarding the relationship between art and reality. "Im Exil stellt sich die umfassende aristotelische Frage nach Wesen und Aufgabe der Kunst neu," she argues. "Wirklichkeit stellt sich als ästhetisches und erkenntnistheoretisches Problem dar, das die Möglichkeit der Wirklichkeitsabbildung in Frage stellt und andere Blickwinkel auf Kunst und Literatur entwickelt." ${ }^{13}$ Englmann takes the point that these problems present themselves before 1933, but she argues cogently that the severe breaks that constitute exile create the opportunity for a more thoroughgoing reconceptualization and re-tooling of literary representation. Simply put, the understanding of literature as a reflection of and intervention into society, a notion of Gegenwartsbindung to which even experimental writers had clung (consciously or not) in the Weimar years, was dealt a death blow by the events and fallout of 1933 .

One can trace the impact of these breaks on Brecht by considering a selection of journal entries from 1940. I start with an entry from 19 August that is characteristic in both its depressive tone and its deliberative intensity:

Im Augenblick kann ich nur diese kleinen Epigramme schreiben, Achtzeiler und jetzt nur noch Vierzeiler. Den 'Caesar' nehme ich nicht auf, weil der 'Gute Mensch' nicht beendet ist. Wenn ich zur Abwechslung den 'Messingkauf' aufschlage, ist es mir, als werde mir eine Staubwolke ins Gesicht geblasen. Wie kann man sich vorstellen, dass dergleichen wieder Sinn bekommt? Das ist keine rhetorische Frage. Ich müsste es mir vorstellen können. Und es handelt sich nicht um Hitlers augenblickliche Siege, sondern ausschließlich um meine Isolierung, was die Produktion betrifft. (BFA 26: 413-414)

Now in Finland, Brecht had reached a state of near-paralysis with these three large projects: the Caesar novel, a historical narrative parable of dictatorship; Der gute Mensch von Sezuan, an epic-dramatic parable of bourgeois morality's inherent contradictions and its collapse under capitalism; and the dramaturgical dialogues of the Messingkauf. The passage's sole metaphor sig- 
nifies the fundamental conceptual problems cast into sharp relief as history overtakes poetics. The resulting awareness is jarring: one's creative theory (represented here by Messingkauf) and practice (Der gute Mensch, Caesar), despite all one's efforts to remain current, have become detached from the times. The dust accumulates with each stroke of the pen or palpation of the typewriter key. The structural similarity between the unwanted divorce of poetics and history thus revealed in the journals and the regretted divorce of the visceral and intellectual as thematized in "An die Nachgeborenen" cannot be overlooked. In both cases, one's missteps interlink with one's isolation; both thought and act only exacerbate the tearing-away. The poem suggests the need for a reconceptualization that will repair the breach; the journal entry states that need explicitly.

The metaphorical dust emanating from Messingkauf ends up in Brecht's face, and he is the first one who must believe there is a point to it all-otherwise the experimenter will destroy the experiment before it has a chance to bear fruit. The tearing-away from context, public, and (as Robert Cohen has observed) producer-collectives ${ }^{14}$ that exile involved would be crippling to any writer, but this spatial separation anxiety alone is not a full explanation for Brecht's near-paralysis. If the spatial disconnect of exile had both forced Brecht into a tactically insignificant quadrant on the social battlefield and brought him to awareness that poetry could pretend no capacity to deliver a direct social punch, then overcoming the paralysis would have to involve rethinking literary representation and its relationship with reality. Part of this rethinking involved a consideration of the technologies and pace of modern life more thorough than any that Brecht had previously engaged in, and we find evidence of this reconsideration in an entry from 8 June 1940:

Das Tempo wird zu einer neuen Qualität der Kriegshandlungen. Der deutsche Blitzkrieg wirft alle Berechnungen über den Haufen, indem die vorhergesehenen Vorgänge so schnell eintreffen, dass ihre Folgen ganz unvorhergesehen sind. Und die Technik fügt dem Kriegstheater eine neue Dimension zu; das Schlachtfeld wird zum Schlachtwürfel oder Schlachtraum. Und die armen Franzosen verstehen gar nicht, was passiert: den Bewegungskrieg führen sie wie einen Stellungskrieg. (BFA 26: 377)

Here we find Brecht anticipating speed theorist Paul Virilio, who observes: "With the National Socialist lightning-war, the old, outmoded frontier wall disappears, ostensibly replaced by the rapid path. Already, the German nation is no longer exactly where its famous boots-the symbol of its army-fall, but rather under the tracks of its tanks, in the motor force of its 'steel front."' 15 Following the rapid path means taking over the circulatory system on which territorial survival depends, and the rapidity with which German forces accomplished this objective in the first year of the war, if we follow Brecht, renders even its planners' calculations inaccurate. 
By virtue of this velocity, the German Bewegungskrieg threatens to bring the fight to everyone: it can move into all spaces of life and occupy all subjects, rapidly foreclosing the possibility of resistant thought or action. As Brecht puts it in another entry from around the same time, "Der deutsche Generalstab hat sich durch die Mechanisierung freigemacht von den persönlichen Eigenschaften der Soldaten, vom 'Geist der Truppe.' Der Soldat wird unter die Kampfmittel gerechnet. Die Motoren 'nehmen ihn mit.' Die Pünktlichkeit der Operationen wird nicht mehr durch den Verantwortlichkeitssinn, sondern durch die Stoppuhr gewährleistet" (BFA 26: 371-372). As people become one more component of war materiel, singular subjectivity and the body as a vehicle of one human life simply become irrelevant. We can therefore say of wartime military abstraction what Lethen says of the neusachlich bracketing of morality: it ultimately aims for "die Preisgabe des Körpers." ${ }^{16}$ Blitzkrieg planning and neusachlich moral critique share the objective of rendering bodies such that they, as traditionally understood human beings, no longer matter.

These issues, raised initially in the discourse on total mobilization tied to World War I, had broader and deeper implications in World War II exactly because war became so mobile. The Great War encompassed and informed the subdivided spaces of military, political, economic, social, and cultural life, but those spaces were considered distinct, the field of combat delimited, and the human subject capable of critically evaluating the conditions of its actions in a given environ. In the "Deutsche Kriegsfibel 1937," Brecht could still write "General, der Mensch ist sehr brauchbar. / Er kann fliegen und er kann töten. / Aber er hat einen Fehler: / Er kann denken" (BFA 14: 92). Implicit in this "er" is a recognition of dominating regimentation and an insistence on the possibility that oppositional impulses can emanate from the rational subject. These reflect a critical position informed on the one hand by World War I and on the other by an Enlightenment tradition that is increasingly viewed in exile as fragile and suspect. ${ }^{17}$ By 1940, instead of remaining subdivided and static, space becomes fluid, and war permeates every point within a given battle-cube. That permeation, once achieved, renders traditional conceptions of both time and space invalid. For those in battle, there is only now, only medias res. It is the opposite effect of the "Gedichte im Exil" poet's attempt at permanence without presence: there is only immediate engagement and no sense of what could lie outside or come later. The soldier now inhabits a space that parallels and perverts that space outside time for which the Hauspostille poet longs, making the achievement of a critical position vis-à-vis events virtually impossible.

Resistance should theoretically have come from progressive collectives, but such collectives had faded in the face of the "politische Atomisierung" that Brecht saw as a "Resultat der militärisch-polizeilichen Zusammenballung der Riesenmassen" (BFA 26: 378). In his gravitation toward Marxism and immersion in projects of collective production ${ }^{18}$ and reception in the late 
1920s and 1930s, Brecht had sought a progressive cultural-political dynamization of the masses; but his self-conceptualization as a speaker of the masses, as Marianne Streisand has shown, had ample blind spots, ${ }^{19}$ and his model of progressive collectivism was undone by his misjudgment of the collectivist subject's capacity to draw critical distinctions amid the affective effervescence of mass formations. ${ }^{20}$ These problems became increasingly visible as the Nazis trounced leftist artists and intellectuals in the battle for the late-Weimar street. As Virilio notes, "The German National Socialists [... ] take over the German State, city by city, or rather street by street, before spreading highway by highway toward the neighboring territories, as if the German masses, "set in motion' by their leaders' dynamic declarations, could no longer be stopped." Brecht confirms the growing perception of the Nazi machine's unstoppability that Virilio describes retrospectively. From Finland, Brecht writes that the Nazis are finishing off in 1940 whatever promise of the French Revolution was able to survive the Reign of Terror and the despotism that followed: "Die letzten Darbietungen der Marseillaise werden jetzt von den deutschen Stukas zum ewigen Schweigen gebracht" (BFA 26: 377).

So much for the optimism of the Svendborg poem "Der große Oktober der Arbeiterklasse," in which the consciousness of international socialism allows the Spanish Republican soldier to look skyward with "geringerer Sorge" as fascist planes approach (BFA 12: 46). As it floods Europe's arteries and capillaries, the Blitzkrieg of 1940 forms a paradigm for all fields of conflict fusing into one large field of war, the entire sphere of life becoming a three-dimensional realm of combat. This permeating is also a docilizing and a silencing: the liberal-revolutionary spirit is rendered inert, what could have become a social-revolutionary mass becomes a militarized mass, and the progressive voice is lost. It is a voice that suffered crippling blows at every Nuremburg rally, but it is also debilitated by self-inflicted wounds that trace back to the late republic. The significance of the silencing cannot be overlooked, for even the most alert, perceptive ear cannot receive a message not transmitted. The voice and the ear-those basic mechanisms of human communicative circuits - were what Brecht struggled to re-imagine in exile, and given the material dispersal of the potential members of his speaking and listening community, re-thinking writing and reading was all the more urgent in the campaign to repair the breaches from which issued both the neusachlich cool subject and the militarized mass.

\section{Exile's textual metropolis}

We often associate the artist's task with loosening strictures and expanding or negating limits. But in the face of a technologized, accelerated mode of war, which creates a fluid space of combat from which the artist recoils in horror, recovering fixity becomes paramount —at least enough fixity to anchor 
a noncompliant orientation impossible to achieve within the flux of war. The dynamism of the militarized mass and the extension of the fascist mode of combat into ever more spaces of life raised the question of whether new progressive modes of subjectivity were indeed still possible. As if the National Socialist-led German masses could not be stopped, Virilio writes; the rapid path ostensibly replaced the outmoded frontier. His phrasing asserts our capacity to recognize in retrospect the deficiencies of Nazi paradigms. To what extent did Brecht share this capacity during the actual course of events? It was at least clear to him by 1940 that the Spanish Republican soldier's socialist faith would no longer be sufficient. The times called for a subject that, in its very constitution, would be more likely to thwart the design of the Nazi culture of motion, in which the logic of movement negated the possibility of critical reflection and thus generated political stasis.

Goebbels's public was not meant to ponder, and reading, Virilio reminds us, "implies time for reflection, a slowing-down that destroys the mass's dynamic efficiency." ${ }^{21}$ Both anticipating and extending Virilio's point, Brecht's grapplings suggest that the right kind of reading-writing joint effort would not only reduce the mass's efficiency but also make possible perception of those modern contradictions that mass intoxication rendered inscrutable. Writing and reading could cultivate a virtual standstill mode of subjectivity, making the subject more able and apt to face the paradoxes of modernity than to avert these via participation in fascist mass politics or stubborn adherence to neusachlich attitudes and practices, the failings of which had been exposed by the trials of exile. At stake were the insights into modernity's contradictions that Brecht (and he was certainly not alone) had accumulated by 1940, a store of knowledge he believed could yet be made useful if only it could escape, as David Midgley puts it, "the blizzards of the times.".2

This obliteration anxiety receives cogent treatment in a recent essay by Jochen Vogt. Analyzing the poem "Die Legende von der Entstehung des Buches Taoteking auf dem Weg des Laotse in die Emigration," for example, Vogt traces how the physical risk to Lao Tzu will endanger the wisdom carried only by the medium of his body: "Nur als Niederschrift," Vogt observes, "kann [die Weisheit], angesichts der Hinfälligkeit des Weisen und der Gefahren des unbekannten Draußen, gesichert werden. ${ }^{.23}$ Writing guarantees transferability and thus accessibility and applicability of knowledge, making it possible for later recipients, through astute reading, to appropriate and activate what was known to the writer.

Vogt draws a distinction in his discussion of content-survival between Erinnerung, personal recollections associated with modern notions of individuality, and memoria, a more pre-modern sense of collective memory. It is damnatio memoriae, the "geplante und gewaltsame Auslöschung ihrer Worte und Werke," that poets most fear. This fear is dramatized in "Besuch bei verbannten Dichtern," a narrative poem that depicts an anonymous poet's visit to Dante's limbo, the maestro himself at the visitor's side: 
... aus der dunkelsten Ecke

Kam ein Ruf: 'Du, wissen sie auch

Deine Verse auswendig? Und die sie wissen

Werden sie der Verfolgung entrinnen?' 'Das

Sind die Vergessenen,' sagte der Dante leise

'Ihnen wurden nicht nur die Körper, auch die Werke vernichtet.' (BFA 12: 35)

As Vogt notes, the Tao legend and the visit to banished poets paradoxically complement one another: "Dort muss das Wissen entäußert, vom bedrohten Körper getrennt werden und findet sein vorläufiges Exil in der Schrift; hier ist die Auslöschung der Schriften reale Gefahr und die kulturell überwundene Stufe der Oralität, das Auswendiglernen und Weitersagen, letztes und seinerseits höchst prekäres Residuum der memoria." ${ }^{24}$ In other words, the demands of transmission will vary according to tactical situation (hence Brecht's intense scrutiny of the unprecedented battlespheres of 1940); and a link (via orality) between poetry and body persists alongside increasingly sophisticated technologies of textual (re)production.

While spatial displacement makes immediate interpersonal contact impossible, communication can be extended — spatially and temporally - through the medium of writing. The problem, however, is that the medium cannot guarantee the structural integrity and durability of communicative exchange. As Egyptologist and cultural-memory theorist Jan Assman puts it, "Ohne die Schrift [ . . ] lässt sich Kommunikation nicht in Raum und Zeit ausdehnen. Aber das ist nur eine notwendige, keine hinreichende Bedingung [ . . . Die Lesbarkeit der Schrift ist nicht Sache der Schrift, sondern derer, die mit ihr umgehen." ${ }^{25}$ Brecht's sense of urgency in matters of form, as the journals confirm, stems from a concern with duration (Dauer) that had been present since he first started noting his "classical" tendencies in the early 1920s. As Vogt argues, this sense of Klassizität had to do not with a "Klassikerkult im Sinne der 'gipsernen Büste"" but with a growing obsession with problems of duration and readability. ${ }^{26}$

These matters became acute in exile, the multiple dissolutions of which created the perfect opportunity for testing communicative classicality. Like the deliberations over emotion and subjectivity, this line of thought as well reached back to the Weimar years. Consider these verses from the 1929 poem "Über die Bauart langdauernder Werke":

Wie lange

Dauern die Werke? So lange

Als bis sie fertig sind

Solange sie nämlich Mühe machen

Verfallen sie nicht.

[...]

Die zur Vollständigkeit bestimmten

Weisen Lücken auf

Die langdauernden 
Sind ständig am Einfallen

Die wirklich groß geplanten

Sind unfertig. (BFA 14: 34-35)

The wordplay on fertig leaps out first: the duration-limit is the point of completeness - or is it the point of exhausted collapse? The works that last, paradoxically, are those that display their blind spots, their deficiencies, their impending breakdown - offering negative knowledge to go with the positive. Thus gaps play the crucial role of connecting writer and reader in shared meaning-making labor. Lücken are, as Vogt puts it, the "zentrales Strukturelement" ${ }^{\prime 27}$ of durable works.

A Lücke is space without construction, both frustrating and exciting in its openness. And one can achieve greater insight into Brecht's signification of classicality when one contemplates these gaps alongside a space that can both encompass and oppose them: the city. In a 20 September 1940 journal entry, Brecht deploys an image of urban space in a particularly pregnant characterization of diachronic literary communication:

Was eine nationale Literatur und hiermit eine Literatur schlechthin ist, ging mir eigentlich erst diesen Sommer auf, als ich mehr Englisch las. Diese große Aufeinanderfolge von Geschlechtern in der literarischen Welt, diese Kämpfe und Kommunikationen, diese Neuerungen, welche Korrekturen sind, diese Tradition, welche den Fortschritt erleichtert, statt ihn zu hemmen! Diese Literaten dreier Jahrhunderte scheinen in einer einzigen Stadt zu gleicher Zeit zu leben, sie kennen sich und rivalisieren miteinander, und man hat eine Börse, welche Werte notiert, man hat Kriege und Schlachten, echte Daten, wahre Monumente. (BFA 26: 425, my emphasis)

The passage suggests that the emerging metaphor of a city of writers and texts forms part of a poetological watershed, which recasts notions of tradition and monument that one generally attributes to conservative cultural politics. This recasting connects with the need to recover fixity noted above. In this city, tradition furnishes crucial points of reference and contact that make innovation possible. (In a space of zero orientation, after all, there can be no sense of what moving forward entails.) And as later writers come to grips with earlier ones, the tension generated is also a communicative exchange. In addition, the city belongs to a spatially and temporally unbound reading public. This public would hold shares in the texts competing on the market and thus have stakes in the textual battles and wars. In viewing the monuments, the public would make them meaningful-just as Brecht does in this passage, writing as a reader.

The true monuments, one extrapolates, would be not bombastic vestiges of a time now ended but a dynamic semantic interface between temporal points. Like the city (itself never finished) and the literary labor that gives the metropolis its form, the monuments would combine fixity and flux, clearly readable surfaces and significant gaps. They would be open monuments, built 
not to command critically inert reverence but to resonate in a way that fosters exchange. Walking among the monuments, interacting with them and other meaningful surfaces of the city, readers would discover neither a verisimilar reflection of the world nor a solution to the world's problems, but rather something both more humble and more ambitious: the possibility of a more aware experience of salient structures and phenomena of modern life. As Englmann remarks of the 20 December 1940 journal entry: "Wenn Brecht formuliert: 'Die Welträtsel werden nicht gelöst, sondern gezeigt,' so drückt er damit aus, dass sich die Funktion der Literatur keineswegs im Entwerfen von Botschaften erschöpft, viel wichtiger ist die Frage, wie Strukturen der Wirklichkeit—oder ihrer Auflösung —im Text sichtbar gemacht werden können." ${ }^{28}$ The writer must achieve this making-visible in both social and literary reality; it is what makes the utterances of the literary voice-that corporally grounded orality that renders sensual effects of form and intellectual effects of content inseparable - worthy of note by those who participate in those realities. In the case of Brecht's exile poetry, the riddles range from the geopolitical to the subject-internal: the new scope of war is scrutinized, dilemmas of modern subjectivity are illuminated, flaws of the cold Weimar types are exposed, and an opportunity thus materializes for later readers not to resolve the definitive tensions of modernity but to tackle the problems in a way that Brecht and his contemporaries could not.

In entering the city, readers would not be magically compelled to take to the antifascist barricades, but those who achieved a complex relationship with the metropolis would cultivate simultaneously an intellectual and sentimental profile that would be less compatible with such modes of aesthetic and political organization as those employed by Goebbels and Co. during the early triumphs of National Socialism. The metropolis is demarcated but dynamic, a space in which it becomes possible to counter the stasis via flow that the fascist policing of the masses pursues. Strictly speaking, the textual city is a utopia, a no-place, but its distinct reality is the vital basis of its autonomy.

The question of art's autonomy, always a thorny issue with Brecht, receives elegant treatment in his remark on Wordsworth from 24 August 1940: "Die Kunst ist ein autonomer Bezirk, wenn auch unter keinen Umständen ein autarker" (BFA 26: 417). An autonomous region is one that governs itself"verwaltungsmäßig unabhängig," as Das digitale Wörterbuch der deutschen Sprache succinctly puts it. But if art sets and follows its own rules, it is still by no means autarchic: "sich selbst versorgend," self-sufficient. ${ }^{29}$ From this we conclude that art, while not necessarily subject to social context in its selfforming, is nonetheless dependent on (thus bound to) that context because art is incapable of sustaining itself. Art divorced from social reality will deplete itself; poetry is a social practice, even if not a politically catalytic one. This, not the fantasy of social intervention, is the Gegenwartsbindung that becomes clear in exile. 
We thus find in these journal entries and poems fragmentary blueprints and small construction projects for a textual metropolis, motivated by a sense of writing's transgressions, increasingly informed by the light those transgressions shed on issues of aesthetics and politics that were raised and only partially (sometimes falsely) resolved in the Weimar era. In these projects, formal choices should become content: message should convey its own aporias, medium should display its own shortcomings. The poet of 1940 aimed for a text that is readable but not semantically closed, enacting a making-visible that succeeds only partially. Some of the poems of 1937 met the criteria; others did not. Work continued on a mode of literary transmission that would both apprehend and (in its reception and processing) destabilize the elective affinity between cooled, hardened individual subjects and militarized masses; and this mode could only be deemed successful if the texts' critical soundings of modern subjectivity and literary communication remained readable. These critical soundings - consistently present even if they do not cohere in a systematic critique - are of greater consequence than whatever currents of Marxism may inform the texts reviewed here, for these texts explore problems that exceed dialectical materialism's explanatory scope.

The model of literary communication suggested by Brecht's transmissions of the late 1930s, in the intellectual and sensual interactivity they seek, is compatible neither with a purely visceral, dynamized mass-subject nor with a subject that cannot love. The mode of subjectivity that would dissolve both of those positions was and is an elusive ideal. For Brecht and those of his contemporaries who shared his sentiments, achieving it remained a perfectly unfinished task:

$$
\text { [...] Ach, wir }
$$

Die wir den Boden bereiten wollten für Freundlichkeit

Konnten selber nicht freundlich sein. (BFA 12: 87)

\footnotetext{
${ }^{1}$ Bertolt Brecht, Werke. Große kommentierte Berliner und Frankfurter Ausgabe. Ed. Werner Hecht, Jan Knopf et al. Vol. 12 (Berlin: Aufbau and Frankfurt am Main: Suhrkamp, 1988) 85. All subsequent Brecht citations refer to this edition and will read as follows: (BFA volume: page).

${ }^{2}$ Theodor W. Adorno, Prismen: Kulturkritik und Gesellschaft. Gesammelte Schriften vol. 10.1. Ed. Rolf Tiedemann (Frankfurt am Main: Suhrkamp, 1977) 30.

${ }^{3}$ Ronald Speirs, “The Poet in Time," Brecht's Poetry of Political Exile. Ed. Ronald Speirs (Cambridge: Cambridge UP, 2000) 193.

${ }^{4}$ Sigmund Freud, Das Unbehagen in der Kultur. Studienausgabe vol. 9 (Frankfurt am Main: Fischer, 2000) 191-270.

${ }^{5}$ Helmut Lethen, Verhaltenslehren der Kälte: Lebensversuche zwischen den Kriegen (Frankfurt am Main: Suhrkamp, 1994).

${ }^{6}$ Lethen, Verhaltenslehren der Kälte 37.

${ }^{7}$ Lethen, Verhaltenslehren der Kälte 37.

${ }^{8}$ Lethen, Verhaltenslehren der Kälte 40.

${ }^{9}$ Adorno, "Erziehung nach Auschwitz," Erziehung zur Mündigkeit (Frankfurt am Main: Suhrkamp, 1971) 100.
} 
${ }^{10}$ For a fruitful examination of this problem in connection with the specific issue of truth, see Joyce Crick, "The Fourth Door: Difficulties with the Truth in the Svendborg Poems," Brecht's Poetry of Political Exile 114-134. 26: 413)

${ }^{11}$ See, for example, entries from 8 July 1940 (BFA 26: 400) and 19 August 1940 (BFA

${ }^{12}$ Speirs, "The Poet in Time" 193.

${ }^{13}$ Bettina Englmann, Poetik des Exils: Die Modernität der deutschsprachigen Exilliteratur (Tübingen: Niemeyer, 2001) 54.

${ }^{14}$ Robert Cohen, "Brechts ästhetische Theorie in den ersten Jahren des Exils," Ästhetiken des Exils. Amsterdamer Beiträge zur neueren Germanistik 54. Ed. Helga Schreckenberger (Amsterdam and New York: Rodopi, 2003) 55-70.

${ }^{15}$ Paul Virilio, Speed and Politics: An Essay on Dromology. Trans. Mark Polizzotti (New

York: Semiotexte, 1986) 24

${ }^{16}$ Lethen, Verhaltenslehren der Kälte 13.

${ }^{17}$ See Englmann, Poetik des Exils 32-41.

${ }^{18}$ See Cohen, "Brechts ästhetische Theorie in den ersten Jahren des Exils" 57-58.

${ }^{19}$ Marianne Streisand, "Brecht und das Politische," The Brecht Yearbook / Das Brecht-Jahrbuch 24 (1999) 311-329.

${ }^{20}$ For analysis of a specific case, see Theodore F. Rippey, "Kuhle Wampe and the Problem of Corporal Culture," Cinema Journal 47:1 (2007), 3-25.

${ }^{21}$ Virilio, Speed and Politics 25.

${ }^{22}$ David Midgley, "Svendborg: A Historical Sketch," Brecht's Poetry of Political Exile 24 .

${ }^{23}$ Jochen Vogt, "Damnatio memoriae und 'Werke von langer Dauer': Zwei ästhetische Grenzwerte in Brechts Exillyrik," Ästhetiken des Exils 308.

${ }^{24}$ Vogt, "Damnatio memoriae und 'Werke von langer Dauer': Zwei ästhetische Grenzwerte in Brechts Exillyrik" 313.

${ }^{25}$ Jan Assmann, "Kulturelles Gedächtnis als normative Erinnerung: Das Prinzip 'Kanon' in der Erinnerungskultur Ägyptens und Israels," Memoria als Kultur. Ed. Otto Gerhard Oexle (Göttingen: Vandenhoeck und Ruprecht, 1995) 100-101, qtd. in Vogt, "Damnatio memoriae und 'Werke von langer Dauer': Zwei ästhetische Grenzwerte in Brechts Exillyrik" 314.

${ }^{26}$ Vogt, “Damnatio memoriae und 'Werke von langer Dauer': Zwei ästhetische Grenzwerte in Brechts Exillyrik" 315.

${ }^{27}$ Vogt, "Damnatio memoriae und 'Werke von langer Dauer': Zwei ästhetische Grenzwerte in Brechts Exillyrik" 316.

${ }^{28}$ Englmann, Poetik des Exils 46.

29 “[A] utonom,” DWDS: Das digitale Wörterbuch der deutschen Sprache des 20. Jahrhunderts (Online: Berlin-Brandenburgische Akademie der Wissenschaften) http://www.dwds.de/ ?woerterbuch=1\&qu=autonom, accessed 8 March 2007; "autark," DWDS: Das digitale Wörterbuch der deutschen Sprache des 20. Jahrhunderts (Online: Berlin-Brandenburgische Akademie der Wissenschaften) http://www.dwds.de/?woerterbuch=1\&qu=autark, accessed 8 March 2007. 